\title{
IDENTIFIKASI FAKTOR PREFERENSI POSISI RUANG TIDUR ORANG TUA DAN ANAK DI RUMAH TINGGAL
}

\author{
Asta Juliarman Hatta ${ }^{1 *}$, Hanson E. Kusuma ${ }^{2}$, Dara Fitriani ${ }^{3}$ \\ Sekolah Arsitektur Perencanaan dan Pengembangan Kebijakan, Institut Teknologi Bandung1, \\ Sekolah Arsitektur Perencanaan dan Pengembangan Kebijakan, Institut Teknologi Bandung², \\ Urban Design Laboratory, Graduate School of Human-Environment Studies, Kyushu University ${ }^{3}$ \\ e-mail: *1astajuliarmanhatta@gmail.com,2hekusuma@gmail.com, \\ 3fitriani.dara@rocketmail.com
}

\begin{abstract}
Abstrak_ Ruang tidur adalah ruang utama yang dibutuhkan oleh penghuni rumah untuk tempat beristirahat di rumah tinggal. Salah satu persoalan penting yang perlu diperhatikan agar ruang tidur dapat berfungsi dengan baik sesuai dengan kebutuhan dan kepentingan penghuni rumah adalah posisi ruang tidur di dalam rumah tinggal. Dalam proses menentukan pilihan setiap seseorang memiliki pertimbangan dan kecenderungan yang berbeda yang dipengaruhi oleh pengalaman pribadi. Penelitian ini bertujuan mengungkap faktor-faktor preferensi posisi ruang tidur orang tua dan anak di rumah tinggal. Penelitian menggunakan metode kualitatif dengan pendekatan grounded theory yang diperoleh melalui hasil kuesioner daring yang dibagikan secara non-random sampling. Hasil penelitian mengungkapkan terdapat sembilan faktor preferensi responden dalam memilih tiga posisi ruang tidur orang tua dan anak, yaitu aksesibilitas, keinginan, privasi, kenyamanan, kedekatan, interaksi, keamanan, pengawasan, dan tradisi.
\end{abstract}

Kata kunci: Preferensi; Ruang Tidur; Rumah Tinggal

\begin{abstract}
Bedroom is the main space that is needed by householder as a place to rest at home. One important issue that has to be considered to the bedroom can function properly with the needs and concerns of the householder is the position of bedroom space in the house. In the process of choosing, every person has different consideration and tendency that are influenced by personal experience. The purpose of this research aims to clarify the bedrooms' position preferences of parents and children at home. The research administered qualitative methods by collecting data through online questionnaires that were distributed by non-random sampling. The result of the analysis revealed nine criteria of respondent's preferences in choosing the three positions of parents and children bedroom, namely accessibility, desire, privacy, comfortability, proximity, interaction, security, controllability, and tradition.
\end{abstract}

Keywords: Bedroom; Home; Preference

\footnotetext{
1 Sekolah Arsitektur Perencanaan dan Pengembangan Kebijakan, Institut Teknologi Bandung

2 Sekolah Arsitektur Perencanaan dan Pengembangan Kebijakan, Institut Teknologi Bandung

3 Urban Design Laboratory, Graduate School of Human-Environment Studies, Kyushu University
} 


\section{PENDAHULUAN}

Pada rumah tinggal terdapat beberapa ruangan seperti ruang keluarga, ruang tamu, ruang makan, kamar mandi, ruang tidur, dan ruangan lainnya. Setiap ruangan tersebut memiliki fungsi yang berbeda-beda sesuai dengan kebutuhan aktivitas penghuni rumah (Putra 2014). Ruang tidur merupakan sebuah ruangan yang khusus digunakan sebagai tempat beristirahat (sleeping area) dan juga sebagai tempat menyimpan barang pribadi yang dirahasiakan oleh pemilik rumah (Surowiyono 2003). Menurut Ching and Binggeli (2011), ruang-ruang yang direncanakan dan ditata dengan baik memenuhi kebutuhan manusia berlindung dan bernaung. Perlindungan dan pernaungan memenuhi kebutuhan fisiologis (physiological needs) dan kebutuhan psikologis merasa aman dan nyaman dalam beraktivitas (safety and security needs). Dua kebutuhan tersebut merupakan prasyarat untuk memenuhi kebutuhan sosial (social needs), penghargaan terhadap diri sendiri (esteem needs), dan mengaktualisasikan diri (self-actualization needs)(Maslow 1994).

Dimensi ruangan, besaran perabot, dan pola sirkulasi adalah faktor yang mempengaruhi perencanaan dan penataan ruang tidur (Surowiyono 2003). Andini and Fawzia (2016) dalam penelitiannya mengatakan bahwa ruang tidur yang mudah dan efektif untuk mengatur perabot adalah ruang tidur yang berbentuk persegi dan persegi panjang. Bentuk ruang tidur yang persegi dan persegi panjang dapat membuat penghuni lebih nyaman beraktifitas dan leluasa mengatur perabot interior kamar. Faktor modul besaran ruang memiliki pengaruh untuk mendapatkan tata ruang yang teratur dan sesuai standar kebutuhan manusia. Mauliani dan Sudarwati (2018) mengatakan modul besaran ruang tidur yang berukuran 3x3 meter adalah ukuran yang standar serta memenuhi persyaratan keamanan untuk perletakan perabot dan kebutuhan sirkulasi sehingga dapat dilakukan aktivitas interaksi antara keluarga.

Persoalan terkait letak dan posisi ruang tidur secara tidak langsung memiliki pengaruh besar terhadap kenyamanan penghuni rumah dalam melakukan aktivitas dan beraktivitas (Mauliani and Sudarwati 2018). Mauliani and Sudarwati (2018) mengatakan bahwa ruang tidur sebagai area privat perlu diperhatikan agar penghuni rumah dapat melakukan kegiatan apapun tanpa terganggu dengan adanya kehadiran orang lain di dalam rumah. Permasalahan letak dan posisi ruang tidur juga dapat mempengaruhi kualitas hidup dan kesehatan mental penghuni rumah dalam beristirahat (Hekmatmanesh et al. 2019). Pada penelitian (Hekmatmanesh et al. 2019) dijelaskan bahwa arah dan orientasi ruang tidur memiliki pengaruh yang signifikan terhadap kesenangan, kenyamanan, emosi dan stress bagi penghuni rumah.

Pada rumah tinggal, umumnya orang tua maupun anak memiliki kamar tersendiri dengan posisi ruang tidur yang berbeda. Terdapat beberapa variasi posisi ruang tidur orang tua dan anak sesuai dengan perencanaan tata ruang pada suatu rumah tinggal dan pengalaman kehidupan seseorang. Variasi posisi ruang tidur tersebut antara lain adalah posisi ruang tidur orang tua yang berada di bagian depan rumah (A), ruang tidur orang tua berada di bagian belakang rumah (B) serta posisi ruang tidur orang tua dan anak sama-sama di depan bagian atau di belakang rumah (C). Ilustrasi posisi ruang tidur orang tua dan anak pada layout rumah dapat dilihat pada gambar 1. 


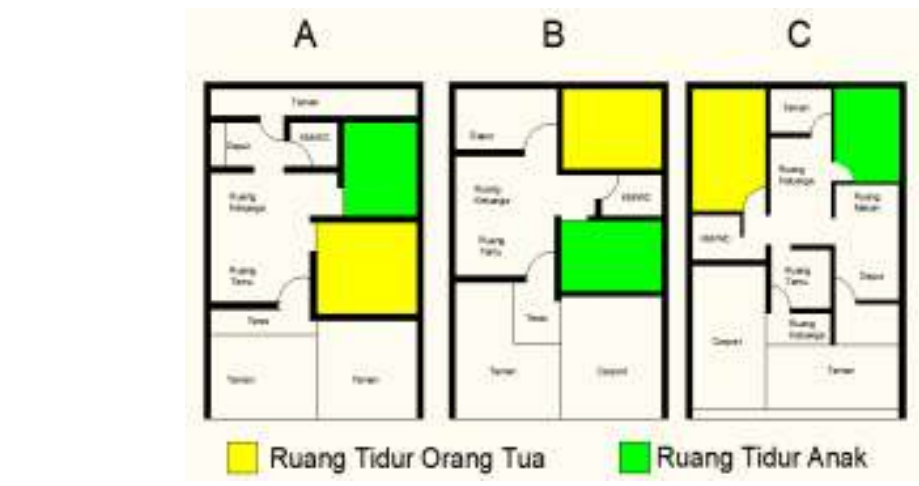

Gambar 1. Ilustrasi Posisi Ruang Tidur Orang tua dan Anak Pada Rumah Tinggal. Sumber: Peneliti, 2018.

Pada ilustrasi gambar di atas, terdapat beberapa variasi posisi ruang tidur orang tua dan anak dalam rumah tinggal. Penentuan variasi posisi ruang tidur tersebut dapat dipengaruhi oleh sebuah persepsi dan preferensi bagi penghuni rumah khususnya orang tua sebagai kepala keluarga (Triyuli 2005). Dalam proses pengambilan sebuah keputusan, preferensi seseorang tidak akan berhenti pada waktu dan aspek tertentu (Syafrina et al. 2018). Zinas and Jusan (2012) mengatakan bahwa persepsi dan preferensi seseorang akan selalu berkembang sesuai dengan dinamika pengalaman seseorang. Pada lingkup rumah tinggal, peran orang tua sebagai kepala keluarga sangatlah penting dalam pengambilan keputusan sehingga kebutuhan anak menjadi suatu prioritas yang sangat perlu diperhatikan bagi orang tua (Anindyajati et.al. 2014). Hal ini terlihat pada temuan (Dewi 2009) bahwa persepsi dan preferensi anak perlu diperhatikan untuk mendesain suatu kamar tidur.

Berkaitan dengan penjelasan di atas, fokus dan tujuan pada penelitian ini ingin mengungkapkan faktor-faktor yang mempengaruhi preferensi seseorang dalam menentukan posisi ruang tidur orang tua dan anak di suatu rumah tinggal. Terkait variasi posisi ruang tidur orang tua dan anak, lingkup dan batasan penelitian ini hanya fokus pada posisi ruang tidur yang berada di area depan dan belakang dalam rumah. Penelitian ini masih membatasi pada kasus rumah tapak (landed houses) tanpa adanya batasan dimensi tertentu seperti rumah tipe 21 ataupun rumah tipe lainnya. Batasan penelitian ini juga tidak memfokuskan pada variasi posisi ruang tidur orang tua dan anak pada bangunan rumah 2 lantai atau lebih dengan kasus posisi ruang tidur yang berada di lantai bawah atau atas rumah.

\section{METODE}

Penelitian ini menggunakan metode kualitatif yang bersifat eksploratif dengan menggunakan pendekatan grounded theory (Strauss and Corbin, 1990; Creswell, 2013). Pendekatan grounded theory dilakukan dari level empirik menuju ke level konsep teori (Kosasih 2018). Teknik yang digunakan adalah menemukan suatu teori dari suatu fenomena dan situasi tertentu berdasarkan data empirik yakni melalui respon atau jawaban seseorang (Strauss and Corbin 1990). Data yang diperoleh kemudian dianalisis dan disusun dalam suatu model hipotesis.

\section{A. Metode Pengumpulan Data}

Pengumpulan data dilakukan melalui penyebaran kuesioner daring secara terbuka (open ended) terkait preferensi posisi ruang tidur orang tua dan anak di rumah tinggal. Penelitian preferensi yang digunakan di dalam penelitian ini adalah stated preferences, bukan revealed preferences (Farasa 2017). Pada stated preferences, objek yang dipersepsi/dievaluasi 
merupakan objek yang ada di dalam imajinasi masing-masing responden, bukan objek nyata yang ada di lapangan . Karena itu, lokasi objek tidak disebutkan di dalam penelitian ini.

Pemilihan sampel (responden) menggunakan metode non-probability sampling dengan teknik snowball sampling. Nurdiani (2014) menjelaskan bahwa teknik snowboll sampling merupakan salah satu metode untuk memilih dan mengambil sampel dalam suatu jaringan dan diperoleh melalui proses bergulir dari satu responden ke responden yang lain. Jumlah total responden yang diperoleh sebanyak 105 orang sesuai hasil kuesioner yang disebar secara online. Kuesioner disebar selama 5 hari dimulai dari tanggal 2 September 2018 sampai dengan tanggal 7 September 2018. Jumlah responden terdiri dari 47 laki-laki dan 58 perempuan. Rentan usia responden dimulai umur 18 tahun sampai 52 tahun dengan rata-rata usia remaja (19-25 tahun) sebanyak 79 orang. Status sosial responden terdiri dari pelajar/mahasiswa sebanyak 58 orang, pns/karyawan 38 orang, wiraswasta 3 orang dan yang belum bekerja sebanyak 6 orang.

Isi pertanyaan kuesioner bersifat (open ended). Pada penelitian ini, responden diminta untuk menjawab pertanyaan kuesioner terkait dengan kesan posisi ruang tidur sewaktu kecil dan harapan responden di masa depan yang akan menjadi preferensi pemilihan posisi ruang tidur orang tua dan anak pada suatu rumah tinggal.

\section{B. Metode Analisis Data}

Pada penelitian ini terdapat tiga tahapan yang dilakukan untuk menganalisis data yang terkumpul yaitu berupa open coding, axial coding, dan selective coding (Strauss and Corbin, 1990; Creswell, 2013). Pada tahap open coding, peneliti mengelompokkan kata kunci yang diperoleh dari jawaban responden ke beberapa kategori besar. Kategori tersebut akan mewakili beberapa kata kunci yang memiliki kesamaan. Selanjutnya, analisis axial coding dilakukan untuk mengetahui hubungan antar kategori tersebut melalui analisis korespondensi. Analisis digunakan untuk mencari hubungan antara alasan dan harapan responden terkait preferensi posisi ruang tidur orang tua dan anak di rumah tinggal. Tahapan terakhir, yaitu selective coding, dilakukan untuk merumuskan model hipotesis akhir penelitian yang akan ditampilkan dalam bentuk tabel.

\section{HASIL DAN PEMBAHASAN}

\section{A. Pengalaman Posisi Ruang Tidur}

Pada tahap awal penelitian ini, peneliti ingin mengetahui bagaimana kondisi posisi ruang tidur orang tua dan anak berdasarkan pengalaman responden semasa kecil pada ilustrasi variasi posisi ruang tidur yang ada pada kuesioner. Hasil ini digunakan untuk mengidentifikasi hubungan antara preferensi dengan alasan responden dalam menentukan posisi ruang tidur orang tua dan anak di rumah tinggal. Posisi ruang tidur yang diperoleh berdasarkan pengalaman responden (lihat diagram 1) yaitu posisi ruang tidur orang tua di depan (50), posisi ruang tidur orang tua di belakang (35) dan posisi ruang tidur orang tua dan anak samasama di belakang atau di depan (20). Posisi ruang tidur yang paling dominan adalah posisi ruang tidur orang tua di depan dan anak di belakang. Kemudian posisi ruang tidur orang tua dan anak sama-sama di belakang atau di depan cenderung sedikit. 


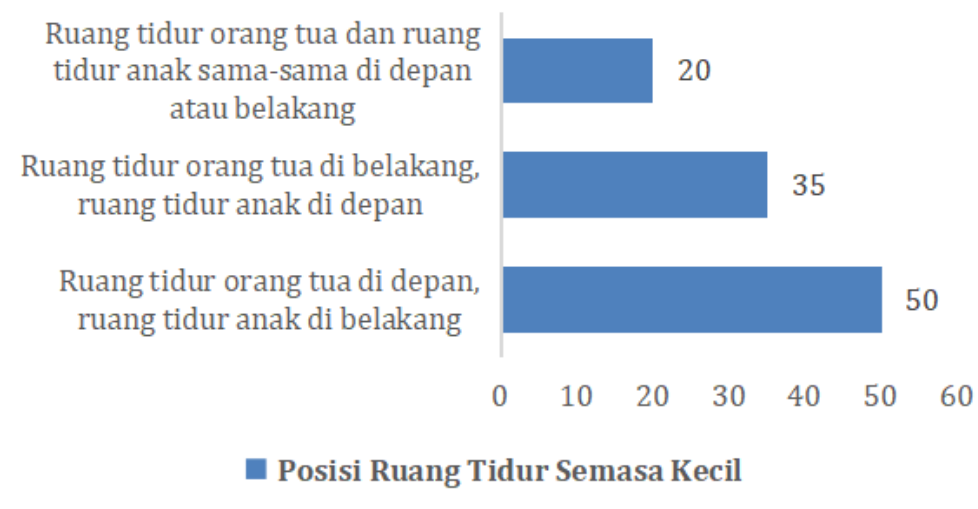

Diagram 1. Histogram Posisi Ruang Tidur Semasa Kecil. Sumber: Peneliti, 2018.

Selanjutnya mengenai harapan yang menjadi preferensi responden terkait posisi ruang tidur orang tua dan anak (diagram 2) diperoleh bahwa posisi ruang tidur orang tua di depan dan anak di belakang sebanyak 44, posisi ruang tidur orang tua di belakang dan anak di depan (22) dan posisi ruang tidur orang tua dan anak sama-sama dibelakang atau didepan (39).

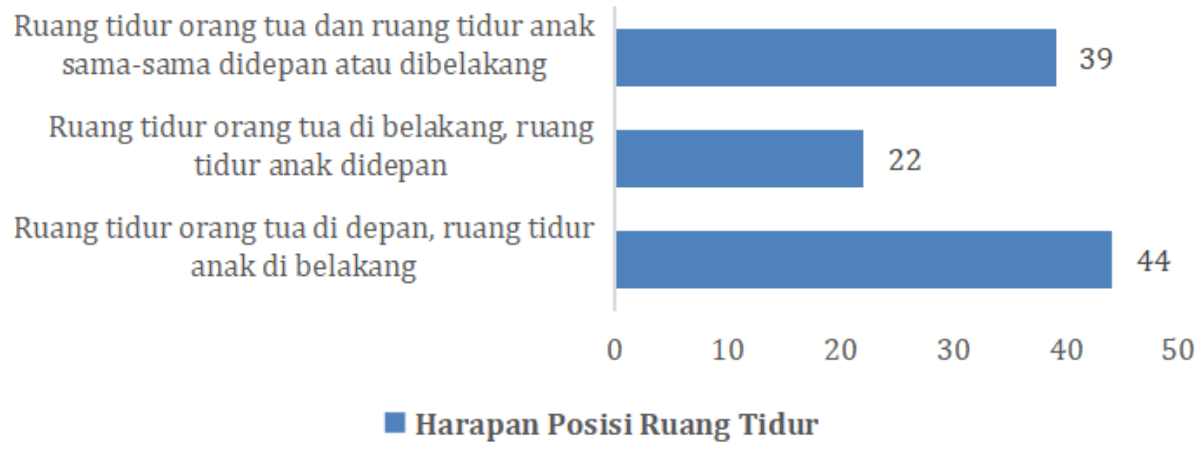

Diagram 2. Histogram Preferensi Posisi Ruang Tidur. Sumber: Peneliti, 2018.

Data yang diperoleh dari diagram di atas menunjukkan bahwa terjadi adanya perubahan persepsi posisi ruang tidur orang tua dan anak. Perubahan yang terjadi dilihat berdasarkan pengalaman pribadi dengan preferensi responden. Perubahan yang signifikan terjadi pada kecenderungan responden memilih posisi ruang tidur orang tua dan anak sama-sama di depan atau di belakang. Perubahan yang terjadi yaitu sebanyak 19 (18\%) yakni dari 20 menjadi 39. Sedangkan posisi ruang tidur orang tua di belakang terjadi perubahan sebanyak 13 yakni dari 35 menjadi 22. Kemudian untuk posisi ruang tidur orang tua di depan perubahan yang terjadi tidak terlalu begitu signifikan dengan perubahan sebanyak 5 yakni dari 50 menjadi 45 . Penjelasan alasan perubahan yang terjadi pada preferensi responden terhadap 3 variasi posisi ruang tidur orang tua dan anak akan dibahas secara lebih lengkap dan jelas.

\section{B. Preferensi Posisi Ruang Tidur}

Seteleh mengetahui bagaimana preferensi responden dalam menentukan posisi ruang tidur orang tua dan anak, langkah selanjutnya akan melihat bagaimana hubungan antara alasan dan preferensi responden dengan hasil open coding. Hasil ini digunakan untuk mengidentifikasi kata-kata kunci yang diperoleh dari jawaban responden berupa data teks. 
Hasil open coding diperoleh sebanyak 16 kata kunci dengan total 144 frekuensi (diagram 3). Kata kunci yang diperoleh yaitu keamanan, pengawasan, aksesibilitas, kebisingan, kenyamanan, pemantauan, adil, kedekatan, keinginan, situasi, tradisi, komunikasi, kedudukan, visual dan alasan khusus. Dari kata-kata kunci tersebut, kata kunci yang paling dominan muncul adalah "pengontrolan" yaitu sebanyak 25 kata kunci.

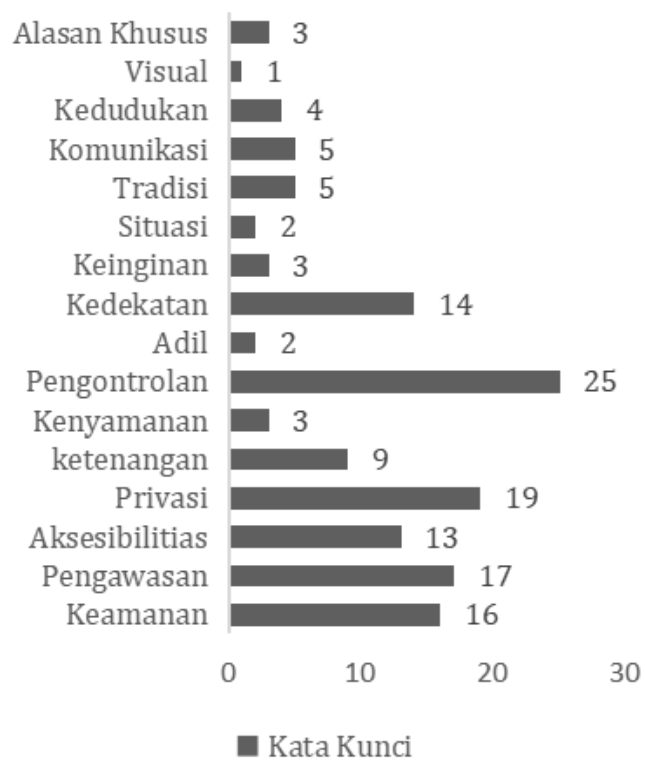

Diagram 3. Frekuensi Kata Kunci Alasan Responden Terkait Preferensi Posisi Ruang Tidur Sumber: Peneliti, 2018.

Penamaan dan pengelompokkan kata kunci diperoleh melalui hasil dari alasan responden yang telah memilih posisi ruang tidur orang tua dan anak dari ilustrasi 3 variasi posisi ruang tidur. Contoh alasan responden yang telah memilih jawaban posisi ruang tidur orang tua di depan(1), posisi ruang tidur orang tua di belakang (2) dan posisi ruang tidur orang tua dan anak sama atau sejajar (3) dapat dilihat pada kutipan di bawah ini.

(1) "Karena biasanya posisi depan berada lebih dekat pada bagian pintu masuk utama rumah, sehingga lebih aman dan lebih untuk mengawasi anak". (Responden 11).

(1) "Orang tua lebih dekat aksesnya ke pintu depan rumah, paling tidak mudah untuk melihat siapa yang bertamu atau mau keluar rumah, anak dibelakang agar bisa terpantau oleh orangtua jika ingin keluar rumah". (Responden 60).

(2) "Karena orang tua memiliki privasiyang lebih utama dibanding anak-anak". (Responden 18).

(2) "Alasannya karena terkadang anak-anak bawa teman main ke rumah. Jadi kalau mereka rebut bagian depan aja tanpa menganggu kenyamanan istirahat orangtua yang kamarnya ada di belakang". (Responden 38).

(3) "Selama hidup bersama tidakakan bisa $100 \%$ orang tua mengawasi anaknya, sehingga setidaknya komunikasi yang maksimal bisa dilakukan didalam rumah". (Responden 68).

(3) "Agar dekat terus dengan anak dan tidak ada jarak dan supaya adil dan tidak dibedakan-bedakan". (Responden 69). 
Setelah pengelompokkan kata-kata kunci yang diperoleh hasil dari responden, selanjutnya dilakukan tahap open coding mengenai alasan responden terkait preferensi posisi ruang tidur orang tua dan anak yakni sebanyak 9 kategori (139 frekuensi). Kategori diperoleh dari kata kunci yang telah dianalisis menggunakan analisis distribusi. Hasil open coding mengenai alasan responden terkait preferensi dalam menentukan posisi ruang tidur orang tua dan anak dapat dilihat pada tabel 1.

Table 1. Hasil Open Coding Terkait Preferensi Posisi Ruang Tidur Orang tua dan Anak

\begin{tabular}{|c|c|c|}
\hline No. & Kata Kunci yang mewakili & Kategori (Frekuensi) \\
\hline 1. & Mengawasi & \multirow{3}{*}{ Pengawasan (42) } \\
\hline & Memantau & \\
\hline & Mengontrol & \\
\hline 2. & Aman & \multirow{2}{*}{ Keamanan(16) } \\
\hline & Melindungi & \\
\hline 3. & Area Privat & Privasi (19) \\
\hline 4. & Mudah Mengakses & Aksesibilitas (13) \\
\hline 5. & Dekat & Kedekatan (14) \\
\hline 6. & Ketenangan & \multirow{3}{*}{ Kenyamanan (13) } \\
\hline & Jauh dari kebisingan & \\
\hline & Kenyamanan Visual & \\
\hline 7. & Komunikasi & Interaksi (5) \\
\hline 8. & Alasan Khusus & \multirow{3}{*}{ Keinginan (8) } \\
\hline & Penyesuaian kondisi & \\
\hline & Adil & \\
\hline & Kedudukan & \multirow{2}{*}{ Tradisi (9) } \\
\hline & Sesuai Adat/Tradisi & \\
\hline
\end{tabular}

Berdasarkan hasil pengelompokan kata kunci (open coding), kategori yang paling dominan muncul yaitu kategori pengawasan sebanyak 42 (30\%), keamanan sebesar 16 (9\%),privasi sebanyak 19 (14\%), aksesibilitas sebanyak 13 (9\%), kedekatan sebanyak 14 (10\%),kenyamanan sebanyak 13(9\%), dan interaksi sebanyak 5 (4\%), keinginan sebanyak 8 (6\%) dan tradisi sebanyak 9 (6\%). Frekuensi kategori berdasarkan alasan responden terkait preferensi posisi ruang tidur orang tua dan anak dapat dilihat pada diagram 4.

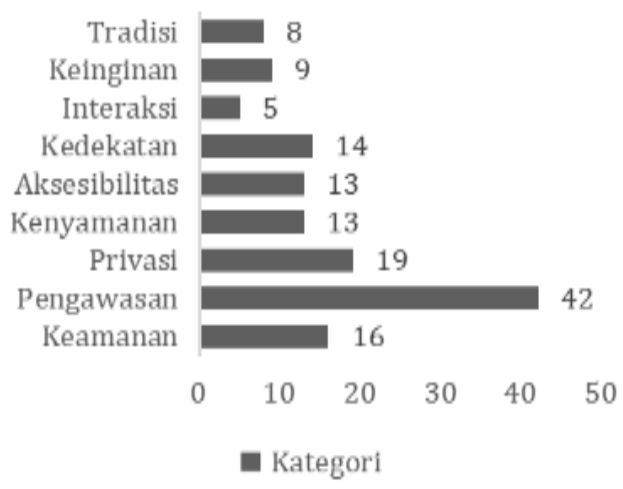

Diagram 4. Frekuensi Kategori Alasan Responden Terkait Preferensi Posisi Ruang Tidur Sumber: Peneliti, 2018. 
Aspek yang paling dominan muncul terkait preferensi responden dalam menentukan letak posisi ruang tidur orang tua dan anak adalah kategori pengawasan. Kecenderungan seseorang memilih posisi ruang tidur tersebut didasari bagaimana agar orang tua dapat mengawasi, memantau dan mengontrol kondisi dalam rumah dan kegiatan anak di dalam rumah. Pengawasan terhadap sesuatu yang datang dari luar rumah juga menjadi aspek penting yang perlu diperhatikan.

Kemudian pada aspek keamanan posisi ruang tidur orang tua dan anak disesuaikan berdasarkan faktor kebutuhan penghuni akan pengtingnya rasa aman di dalam rumah. Posisi ruang tidur di rumah tinggal dapat mempengaruhi rasa aman bagi anak ataupun orang tua ketika sedang beristirahat. Faktor keamanan juga dipengaruhi oleh bagaimana peran orang tua melindungi anak di dalam rumah.

Aspek privasi adalah aspek penting yang mempengaruhi penentuan posisi ruang tidur orang tua dan anak di dalam rumah. Aspek privasi ruang tidur berfungsi sebagai tempat menyimpan barang pribadi. Privasi ruang tidur juga perlu terpisah dari kegiatan atau aktivitas di ruang tamu atau ruang publik. Aspek kenyamanan merupakan aspek non-fisik yang berhubungan dengan kenyamanan lingkungan(Syafrina et al. 2018). Aspek kenyamanan mempengaruhi posisi ruang tidur dengan lingkungan ruangannya serta membutuhkan ketenangan yakni jauh dari kebisingan (Putra 2014). Secara visual, pemandangan ke area taman belakang rumah merupakan kebutuhan akan rasa nyaman bagi penghuni rumah.

Posisi ruang tidur dalam rumah juga sangat erat kaitannya dengan faktor aksesibilitas. Faktor aksesibilitas sangat erat kaitannya dengan aspek interaksiyang memudahkan akses dalam menempuh jarak antar kamar orang tua dan anak. Faktor aksesibilitas juga dapat digunakan sebagai kemudahan komunikasi, mengobrol dan interaksi yang dapat mendukung kebutuhan penghuni rumah. Kemudahan aksesibilitas dan kemudahan komunikasi serta interaksi menimbulkan adanya hubungan kedekatan antara orang tua dan anak. Kedekatan ini mempengaruhi penghuni rumah dalam memenuhi kebutuhan kegiatan ataupun aktivitas satu sama lain. Faktor kedekatan ini juga memperhitungkan jarak kamar tidur orang tua dan anak yang berarti semakin dekat akan semakin baik dalam menunjang kebutuhan penghuni dalam rumah.

Selanjutnya kecenderungan responden dalam menentukan posisi ruang tidur dan anak didasari atas aspek keinginan dari dalam diri seseorang. Keinginan tersebut meliputi bagaimana seseorang dalam memilih posisi ruang tidur berdasarkan alasan yang khusus. Alasan khusus dipengaruhi oleh keinginan membagi posisi ruang tidur berdasarkan rasa adil dalam diri seseorang, serta hasil keinginan yang dipilih secara spontan.

Pada aspek yang terakhir yang menjadi kecenderungan responden dalam menentukan posisi ruang tidur yaitu aspek tradisi. Aspek ini menjelaskan bagaimana seseorang dalam memilih sesuatu atau menentukan sesuatu masih menggunakan tradisi dan adat yang melekat berdasarkan pengalaman yang dialami. Aspek tradisi ini juga berkaitan dengan kedudukan orang tua di dalam rumah tinggal dimana peran anak menunjukkan rasa hormat terhadap orang tua.

Setelah analisis distribusi dilakukan, selanjutnya akan dilakukan tahapan axial coding dengan proses analisis korespondensi. Analisis korespondensi ini bertujuan mengetahui hubungan preferensi dan alasan responden terkait preferensi posisi ruang tidur dan anak di rumah tinggal. Analisis korespondensi ini menggunakan diagram dendrogram yang kemudian diperoleh nilai $\mathrm{p}$-value $=0.0041$ dengan hasil yang signifikan (diagram 5). $P$-value pada penelitian ini menggunakan nilai $p$-value pearson yang dihasilkan dari aplikasi analisis data 
JMP 13. Hasil analisis signifikan (dapat dipercaya) bila nilai p-value kurang dari 0.05. Nilai signifikan value 0.0041 menunjukkan hasil analisis signifikan dan kemungkinan ketidaktepatan prediksi hasil analisis sebesar $0.4 \%$.

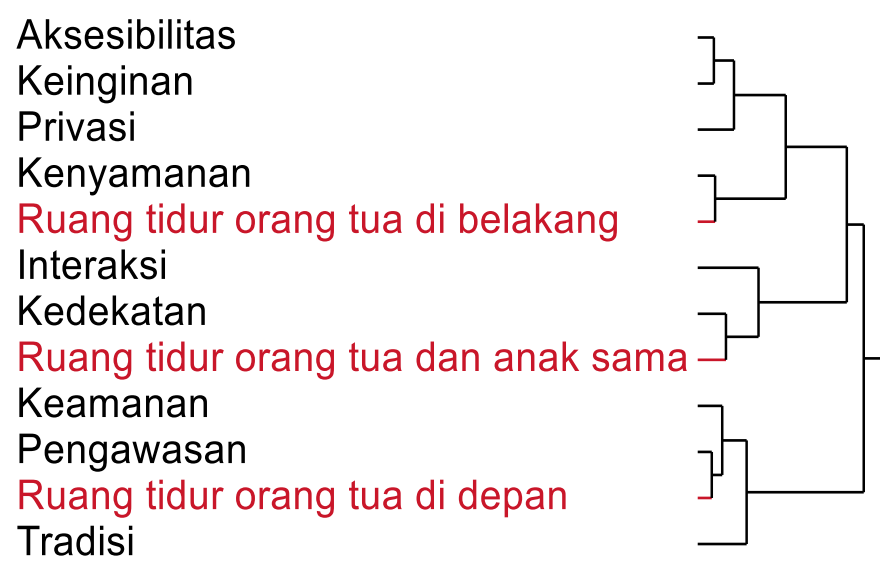

Diagram 5. Analisis Korespondensi antara hubungan dan alasan terkait preferensi responden menentukan posisi ruang tidur orang tua dan anak. p-value $=0.0041$

Sumber: Peneliti, 2018.

\section{Posisi Ruang Tidur Orang tua di Depan (I)}

Responden yang cenderung memilih posisi ruang tidur orang tua di depan dan anak di belakang didasari atas pertimbangan aspek pengawasan, aspek keamanan serta aspek tradisi. Pertimbangan alasan responden terkait aspek pengawasan didasari bagaimana agar orang tua dapat mengawasi, memantau serta mengontrol kondisi dan kegiatan anak di dalam rumah. Pengawasan terhadap sesuatu yang datang dan berasal dari luar rumah juga menjadi pengawasan orang tua terhadap kepentingan dan kebutuhan anaknya (Anindyajati et al. 2014). Aspek keamanan mempengaruhi bagaimana kebutuhan akan rasa naungan dan berlindung (Ching and Binggeli 2011) serta perlindungan terhadap gangguan dari luar rumah seperti kriminalitas (Maslow 1994). Kemudian aspek tradisi yang meliputi bentuk konformitas dan tradisi (Schwartz 2006) yang masih melekat dari dalam diri seseorang akan mempengaruhi pentingnya kududukan orang tua sebagai rasa hormat seorang anak.

\section{Posisi Ruang Tidur Orang tua di Belakang (II)}

Responden yang cenderung memilih posisi ruang tidur orang tua di belakang dan anak di depan didasari atas pertimbangan aspek kenyamanan, privasi, keinginan, dan aksesibilitas. Alasan kenyamanan terkait dengan bagaimana posisi kamar orang tua merasa tenang dan jauh dari kebisingan serta merasa nyaman berada di area yang berhubungan dengan taman belakang rumah (Putra 2014). Kenyamanan lingkungan dapat dibedakan menjadi tiga jenis yaitu kenyamanan termal, kenymanan visual dan kenyamanan audio (Syafrina et al. 2018). Kenyamanan tersebut merupakan aspek penting yang dapat menentukan kebetahan seseorang tinggal di suatu ruangan maupun rumah tinggal. Salah satu contoh kenyamanan audio adalah permasalahan pada kebisingan. Tingkat kebisingan dapat diperoleh dari luar seperti gangguan suara kendaraan bermotor baik di siang ataupun malam hari. Pirrera et al. (2014) mengatakan bahwa penentuan layout ruangan yang baik khususnya pada ruang tidur sebaiknya diposisikan di posisi belakang rumah. Posisi ruangan pada belakang rumah dapat mereduksi tingkat kebisingan yang berasal dari luar bangunan sehingga memberikan kenyamanan bagi penghuni rumah untuk beristirahat. Pada kasus kenyamanan lingkungan lainnya, Syafrina et al. (2018) mengatakan bahwa adanya 
pepohonan dan vegetasi tanaman dalam rumah dapat mempengaruhi kenyamanan visual bagi penghuni rumah serta kenyamanan termal bagi lingkungan rumah. Secara visual, banyaknya pepohonan dan tanaman yang didimoniasi oleh warna hijau dapat membantu manusia merelaksasi tubuh dan memberikan kesan positif bagi tubuh manusia khususnya pada organ penglihatan (Pitaloka et al. 2016). Peran pepohonan dan tanaman dalam rumah juga dapat mempengaruhi sirkulasi udara yang ada pada lingkungan rumah sehingga semakin banyak pepohonan semakin baik juga sirkulasi udara pada lingkungan rumah.

Setiap orang tua memiliki barang berharga seperti perhiasan, surat tanah dan berang berharga lainnya. Posisi ruang tidur orang tua di area belakang merupakan posisi yang dinilai dapat menjaga privasi agar tidak terganggu dari kegiatan yang berada di area tengah dalam rumah (Surowiyono 2003). Oleh karena itu, ruang tidur yang memiliki area privat yang baik secara tidak langsung akan mempengaruhi ketenangan penghuni rumah dalam beristirahat dan beraktivitas dari gangguan tamu yang ada. Faktor keinginan dapat mempengaruhi bagaimana responden menentukan posisi tidur orang tua didasari oleh alasan yang khusus. Alasan khusus tersebut merupakan alasan yang dapat diperoleh berdasarkan pengalaman dan dimanika perilaku seseorang selama hidupnya (Zinas and Jusan 2012). Aspek aksesibilitas begitu erat kaitannya terhadap kemudahan akses ruang tidur orang tua untuk menunjang kebutuhan dan kegiatan di dalam rumah (Pusungulaa et al. 2015). Posisi ruang tidur pada bagian belakang rumahakan memudahkan akses orang tua ke ruangan dapur yang mayoritas berada di belakang rumah sehingga dapat memenuhi kebutuhan makanan keluarga dengan cepat.

\section{Posisi Ruang Tidur Orang tua dan Anak Sama (III)}

Aspek kedekatan dan aspek interaksi adalah aspek yang cenderung mendasari responden menentukan posisi ruang tidur orang tua dan anak sama-sama di depan atau di belakang atau sejajar. Aspek kedekatan dan aspek interaksi memiliki hubungan yang erat kaitannya dengan kebutuhan manusia akan rasa memiliki dan kasih sayang (Maslow 1994). Kegiatan interaksi dan komunikasi sangat diperlukan bagi orang tua dan anak dalam suatu rumah tinggal untuk hubungan kedekatan keluarga. Posisi ruang tidur yang sama sangat akan memudahkan kegiatan interaksi satu sama lain sehingga membuat hubungan kedekatan orang tua dan anak tersebut semakin erat sehingga dapat mempengaruhi pembentukan dan pengembangan karakter anak (Pusungulaa et al. 2015). Hastasari et al. (2018) mengatakan bahwa pada masa pertumbuhan anak, komunikasi dua arah berupa tatap muka perlu diperhatikan dan dilakukan secara intensif untuk mencegah perilaku anak dari perilaku kenakalan remaja. Nasihat terkait ajaran agama, tata karma, pentingnya ibadah dan masalah pergaulan adalah bentuk komunikasi dan interaksi yang perlu dilakukan secara intensif oleh orang tua maupun anak.

Kualitas dan durasi tidur anak maupun orang tua dapat dipengaruhi oleh intensitas interaksi dan komunikasi antara orang tua dan anak (Dubois-Comtois et al. 2019). Semakin dekat dan semakin sering adanya interaksi orang tua dan anak, maka semakin baik juga waktu dan kualitas tidur seorang anak. Dubois-Comtois et al. (2019) mengatakan bahwa daya asuh orang tua merupakan peranan penting untuk membantu dan menyelesaikan permasalahan yang dihadapi oleh anak di kehidupan sehari-hari. Posisi ruang tidur yang memungkinkan terjadinya intensitas interaksi dan hubungan kedekatan antara orang tua dan anak secara tidak langsung dapat memberikan pengaruh yang signifikan terhadap waktu dan kualitas tidur anak maupun orang tua. 


\section{Model Hipotesis}

Setelah dilakukan proses analisis korespondensi, tahapan terakhir yang dilakukan yaitu proses selective coding yaitu merumuskan model hipotesis temuan penelitian terkait preferensi posisi ruang tidur orang tua dan anak. Model hipotesis terkait hasil temuan penelitian akan dibandingkan dengan suatu teori yang merujuk pada teori hirarki kebutuhan (Maslow 1994). Model hipotesis mengenai alasan atau faktor preferensi posisi ruang tidur orang tua dan anak di rumah tinggal dapat dilihat pada tabel 2.

Table 2. Model hipotesis terkait preferensi responden menentukan posisi ruang tidur orang-tua dan anak di rumah tinggal.

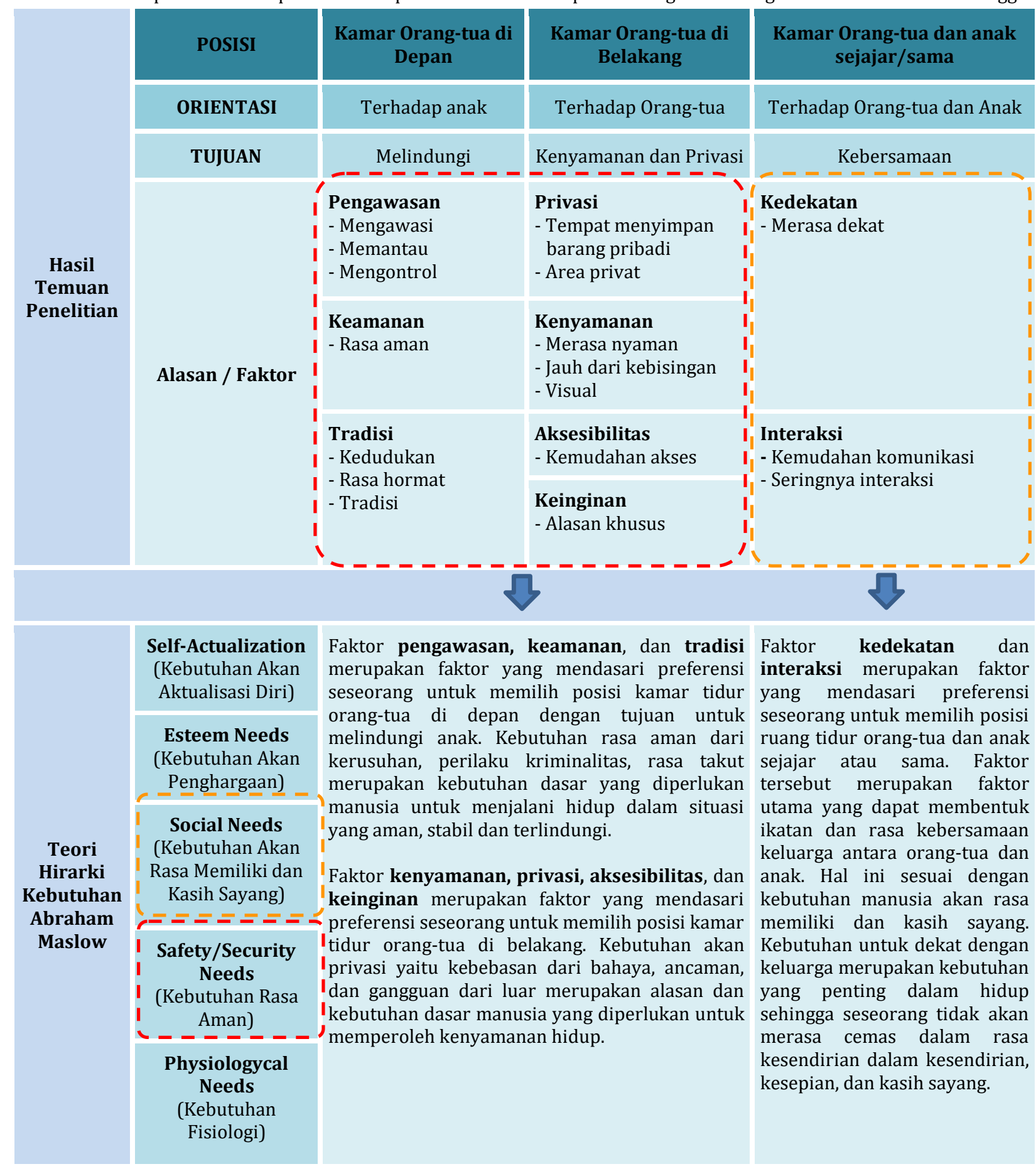




\section{KESIMPULAN}

Pada proses menentukan preferensi posisi ruang tidur orang tua dan anak, terjadi adanya perubahan preferensi karena perubahan pengalaman responden. Terdapat 9 aspek yang mempengaruhi perubahan persepsi responden yaitu aspek aksesibilitas, keinginan, privasi, kenyamanan, kedekatan, interaksi, keamanan, pengawasan, dan tradisi.

Kecenderungan responden memilih posisi orang tua di depan didasari atas aspek pengawasan, keamanan dan tradisi dengan tujuan ingin "melindungi" yang orientasinya tersebut ditunjukkan terhadap kepentingan anak. Responden yang cenderung memilih posisi ruang tidur orang tua di belakang didasari oleh aspek kenyamanan, privasi, keinginan, dan aksebilitas menunjukkan kebutuhan "kenyamanan dan privasi". Kebutuhan tersebut menjadi suatu hal prioritas bagi kebutuhan orang tua. Kemudian hasil analisis terhadap kecenderungan responden memilih posisi orang tua dan anak sama-sama di depan atau di belakang didasari atas aspek interaksi dan kedekatan. Aspek ini menunjukkan prioritas kebutuhan "kebersamaan" yang orientasinya ditunjukkan terhadap orang tua dan anak.

Hasil temuan yang dilakukan dalam penelitian kualitatif dengan pendekatan grounded theory ini masih perlu ditingkatkan untuk mendapatkan tingkat validitas dan reliabilitas yang baik. Tingkat validitas dan reliabilitas hasil penelitian ini perlu ditingkatkan dengan memverifikasi hasil penelitian pada kasus dan konteks yang berbeda. Temuan dari penelitian ini masih berdasarkan perspektif masyarakat umum. Penelitian yang sejenis yang berdasarkan perspektif arsitek perlu dilakukan. Perbandingan perspektif masyarakat umum sebagai pengguna dan perspektif arsitek sebagai perancang merupakan pengetahuan yang menarik untuk memperkaya wacana dunia arsitektur.

\section{DAFTAR REFERENSI}

Andini, Dila Nadia, and Irma Fawzia. 2016. "Komparasi Dimensi Dan Perabot Ruang Tidur Rumah Pribadi Dan Rumah Kost Di Banjarbaru." Archigreen 3 (5): 48-53.

Anindyajati, Dyah Juwita, Ispurwono Soemarno, and Bambang Soemardiono. 2014. "Preferensi Keluarga Muda Dalam Memilih Rumah Tinggal Di Surabaya Berdasarkan Atribut Fisik Dan Infrastruktur Perumahan." In Prosiding Seminar Nasional Manajemen Teknologi XX, B-18 s.d B-19. Surabaya: Program Studi MMT-ITS.

Ching, Francis D. K, and Corky Binggeli. 2011. Desain Interior Dengan Ilustrasi. 2nd ed. Jakarta: Indeks.

Creswell, John W. 2013. Qualitative Inquiry and Research Design: Choosing Among Five Approaches. 3rd ed. Thousand Oaks, California: Sage Publications.

Dewi, Happy Indira. 2009. “Desain Ruang Tidur Berdasarkan Persepsi Dan Preferensi Anak." Nalars 8 (2).

Dubois-Comtois, Karine, Marie-Hélène Pennestri, Annie Bernier, Chantal Cyr, and Roger Godbout. 2019. "Family Environment and Preschoolers' Sleep: The Complementary Role of Both Parents." Sleep Medicine. Elsevier.

Farasa, Nisa. 2017. "Perbedaan Preferensi Antara Stated Preference Dan Revealed Preference Dewasa Muda Terhadap Rumah Tinggal." Jurnal Koridor 8 (2): 126-31.

Hastasari, Chatia, Suranto Aw, and Mami Hajaroh. 2018. "Family's Communication Pattern In Preventing Students'Violence in Yogyakarta." INFORMASI 48 (2): 155-68.

Hekmatmanesh, Amin, Maryam Banaei, Khosro Sadeghniiat Haghighi, and Arezu Najafi. 2019. "Bedroom Design Orientation and Sleep Electroencephalography Signals." Acta Medica International 6 (1). Medknow Publications: 33.

Kosasih, Ahmad. 2018. "Pendekatan Grounded Teori (Grounded Theory Approach) Sebuah Kajian Sejarah, Teori, Prinsip Dan Strategi Metodenya." In Prosiding Seminar Dosen Hasil Penelitian Dan Pengabdian Kepada Masyarakat Tahun 2018.

Maslow, Abraham H. 1994. Motivasi Dan Kepribadian 1: Teori Motivasi Dengan Pendekatan Hirarki Kebutuhan 
Manusia. Jakarta: Pustaka Binaman Pressindo.

Mauliani, Lily, and Wiwik Sudarwati. 2018. "Pengaruh Modul Besaran Ruang Terhadap Tata Ruang Rumah Sangat Sederhana." Nalars 17 (2): 135-44.

Nurdiani, Nina. 2014. “Teknik Sampling Snowball Dalam Penelitian Lapangan.” ComTech: Computer, Mathematics and Engineering Applications 5 (2): 1110-18.

Pirrera, Sandra, Elke De Valck, and Raymond Cluydts. 2014. "Field Study on the Impact of Nocturnal Road Traffic Noise on Sleep: The Importance of in-and Outdoor Noise Assessment, the Bedroom Location and Nighttime Noise Disturbances." Science of the Total Environment 500. Elsevier: 84-90.

Pitaloka, Della Ayu, Rinawati P Handajani, and Damayanti Asikin. 2016. "Perancangan Bangunan SPA Di Malang Dengan Pendekatan Relaksasi Indera Manusia.” Jurnal Mahasiswa Jurusan Arsitektur 4 (4).

Pusungulaa, Alfon, Julia Pantow, and Antonius Boham. 2015. "Pola Komunikasi Keluarga Dalam Membentuk Karakter Anak Di Kelurahan Beo Talaud." JURNAL ACTA DIURNA 4 (5).

Putra, Giwan Hardwika. 2014. "Efektivitas Ruang Dalam Rumah Tipe 36 Ditinjau Dari Perletakan Perabot Terhadap Ruang Gerak Penghuni." E-Journal Graduate Unpar 1 (2): 201-12.

Schwartz, Shalom H. 2006. Basic Human Value: Theory, Measurement, and Applications. Jerusalem: The Hebrew University of Jerusalem.

Strauss, Anselm, and Juliet Corbin. 1990. Basics of Qualitative Research. Sage publications.

Surowiyono, Tutu T W. 2003. Dasar Perencanaan Rumah Tinggal. Jakarta: Sinar Pustaka.

Syafrina, Andina, Angela Christysonia Tampubolon, Suhendri, Nunik Hasriyanti, and Hanson E. Kusuma. 2018. "Preferensi Masyarakat Tentang Lingkungan Perumahan Yang Ingin Ditinggali." RUAS 16 (1): 32-45.

Triyuli, Wienty. 2005. Kebutuhan Perumahan Untuk Keluarga Muda Berdasarkan Perspektif Perkembangan Keluarga Di Kota Palembang. Bandung: Arsitektur-ITB.

Zinas, Bako Zachariah, and Mahmud Bin Mohd Jusan. 2012. "Housing Choice and Preference: Theory and Measurement." In Procedia-Social and Behavioral Sciences, 49:282-92. Elsevier. 